\title{
Impact of the UN convention on the rights of persons with disabilities (UN-CRPD) on mental health care research - a systematic review
}

\author{
Christoph Steinert ${ }^{1}$, Tilman Steinert ${ }^{2}$, Erich Flammer ${ }^{2^{*}}$ and Susanne Jaeger ${ }^{2}$
}

\begin{abstract}
Background: The United Nations Convention on the Rights of Persons with Disabilities (UN-CRPD) aims at stimulating profound changes and social development in many areas of the society. We wanted to examine the impact of the convention on mental health care research up to now by a systematic review.

Methods: We searched relevant electronic databases for empirical studies from the area of mental health which focused directly on the content of the UN-CRPD.

Results: One thousand six hundred ten articles were screened, 36 of which fulfilled the inclusion criteria and came from 22 different countries. 25 studies $(69 \%)$ are related to persons with intellectual disabilities, only 11 to other mental disorders. Study designs were quantitative and qualitative as well. Issues were realisation of the UN-CRPD, implementation and financing, development of instruments, and attitudes towards the UN-CRPD.

Conclusions: In contrast to possible wide-reaching consequences for the organisation of mental health care, theoretical debates prevail as of yet and empirical research is still scarce. Research on the UN-CRPD is more advanced for intellectual disabilities and provides good suggestions for relevant research aspects in major mental disorders.
\end{abstract}

Keywords: UN convention on the rights of persons with disabilities, Human rights, Inclusion, Mental health research

\section{Background}

The United Nations (UN) Convention on the Rights of Persons with Disabilities (UN-CRPD) [1] was adopted by the United Nations General Assembly in 2006 and came into force in 2008. It was ratified by the European Union in 2010 and, in total, by 156 states in 2015. The UN-CRPD is the most recent in a row of UN human rights declarations, beginning from the Universal Declaration of Human Rights in 1948 [2]. The ratifying states acknowledge that the principles of the UN-CRPD should be transposed into their national legislations. Guiding principles are respect for inherent dignity, individual autonomy including the freedom to make one's own

\footnotetext{
* Correspondence: erich.flammer@zfp-zentrum.de

${ }^{2}$ Department of Psychiatry and Psychotherapy I, Centres for Psychiatry Suedwuerttemberg, Ulm University, Versorgungsforschung Weissenau, Ravensburg, Germany

Full list of author information is available at the end of the article
}

choices, non-discrimination, full and effective participation and inclusion in society, equality of opportunity, and accessibility. The general idea of the UN-CRPD is inclusion of disabled people into the society and communities instead of establishing special rules and institutions [3]. Phrasing general principles of human rights, the UN-CRPD is completely applicable to the situation of people with mental illnesses as well as with other kinds of disabilities. Mental illness is not necessarily associated with disability; however, a clear distinction is not required since the UN-CRPD phrases principles which should be valid for all human beings, disabled or not. In the past two years, most interest has been attracted by article 12 (equal recognition before the law). This article does not contain any restrictions due to reduced mental capacity, which led to the idea that such a construct is generally not valid. Consequently in 2013, the special rapporteur on torture and other cruel, inhuman or degrading treatment or 
punishment of the UN Human Rights Council claimed to abolish all kind of coercive treatment as well as substituted decision-making legislations such as guardianship [4]. This has caused considerable concern among psychiatric organisations and stimulated ongoing controversies between psychiatrists and patients' organisations in some countries [5]. However, this current and mostly critical discussion thwarts the engagement with the other aspects of the UN-CRPD - setting goals for mental health care that are not less challenging. The UN-CRPD aims at stimulating profound changes and social development in many areas of the society such as schools, workplace environment and public transportation. On this behalf, the convention calls for data gathering and research in the signatory states. Taking into account this and the huge political relevance of the UN-CRPD, we wanted to examine the impact of the convention on mental health research up to now by a systematic review.

\section{Methods}

Our systematic review aims to identify studies that can be seen as a direct product of the impact of the UN-CRPD on mental health care research. For this purpose, a sequence of selection processes have been performed as described below.

The applied methods are in line with the Preferred Reporting Items for Systematic Reviews and Meta-Analyses (PRISMA) guidelines [6].

\section{Search strategy}

Potentially relevant studies were identified by searching the electronic databases All EBM Reviews, Embase, Ovid MEDLINE(R), Ovid MEDLINE(R) In-Process \& Other Non-Indexed Citations, PsycINFO and PSYNDEX plus Literature and Audiovisual Media. The searching process was performed in Ovid and conducted between the $3^{\text {rd }}$ of July and the $17^{\text {th }}$ of July 2015 . We used the broadest possible search string consisting only of the nouns in the title of the UN-CRPD. Thus, we used the following search term in the multi-field search in Ovid: "convention" AND "rights" AND "persons" AND "disabilities". Taking into account the possible national or regional character of research in this field, no language restrictions were made. This yielded 1610 articles.

\section{Inclusion criteria}

Studies were selected in a two-stage process based on predefined inclusion and exclusion criteria.

In the first step, three criteria were applied. The first inclusion criterion was the requirement that a study was published in the context of the UN-CRPD. Consequently, we excluded articles which did not contain the term UN-CRPD (abbreviated or written-out) in its title, abstract or keywords.
The second inclusion criterion was the condition that the article could be classified as focused on the area of "mental health". For the purpose of our study we defined mental health as mentioning of the terms "mental health", "mental illness", "mental disorder" or explicit mentioning of a diagnosis out of the International Statistical Classification of Diseases and Related Health Problems, 10th revision (ICD-10), chapter F (mental and behavioural disorders). Terms related to intellectual disability (ID, ICD-10 F 7x) such as "intellectual disability" and "mental retardation" also justified inclusion.

The third inclusion criterion required that a study could be classified as empirical. We defined empirical studies as all studies which are the product of research based on experimentation or observation. Thus, all studies were excluded which did not apply any form of qualitative or quantitative research. We assigned those excluded studies to three categories termed 'legal discussion', 'theoretical framework' and 'reviews or overviews'. The category 'legal discussion' refers to all studies which can be assigned to the juridical realm and which are based on norm-driven assumptions. 'Theoretical framework' delineates those articles which are based on theoretical concepts and their discussion. This category also includes case study-approaches without generalisations about a larger population. Finally, the category 'reviews or overviews' captures all non-systematic literature reviews, historical overviews, book reviews and general overviews about specific subject areas. All those excluded studies have in common that they did not produce or analyse real-world data.

We applied no a priori language restrictions to our search since we were confident to find competent translators in our multi-national hospital and research staff for all common languages. The Consort diagram of the selection process is displayed in Fig. 1. Deliberately, the first evaluation was rather lenient to avoid type II errors (false negative) at the expense of type I errors (false positive). The assessment of studies in the first-stage process was based on titles and abstracts.

\section{Study selection}

In the second-stage process we identified those of the studies kept after the first-stage process that focused directly on the content of the UN-CRPD. Three authors (CS, SJ, EF) evaluated their full text content independently. An article was qualified as focusing on the UN-CRPD based on its research question or aim. To be included, the research question or aim must have targeted directly on the UN-CPRD. This condition was fulfilled when the research question either explicitly addressed the UN-CRPD or when it dealt with one of its general principles codified in Article 3. For the latter case, the concepts of inclusion and participation were central keywords. 


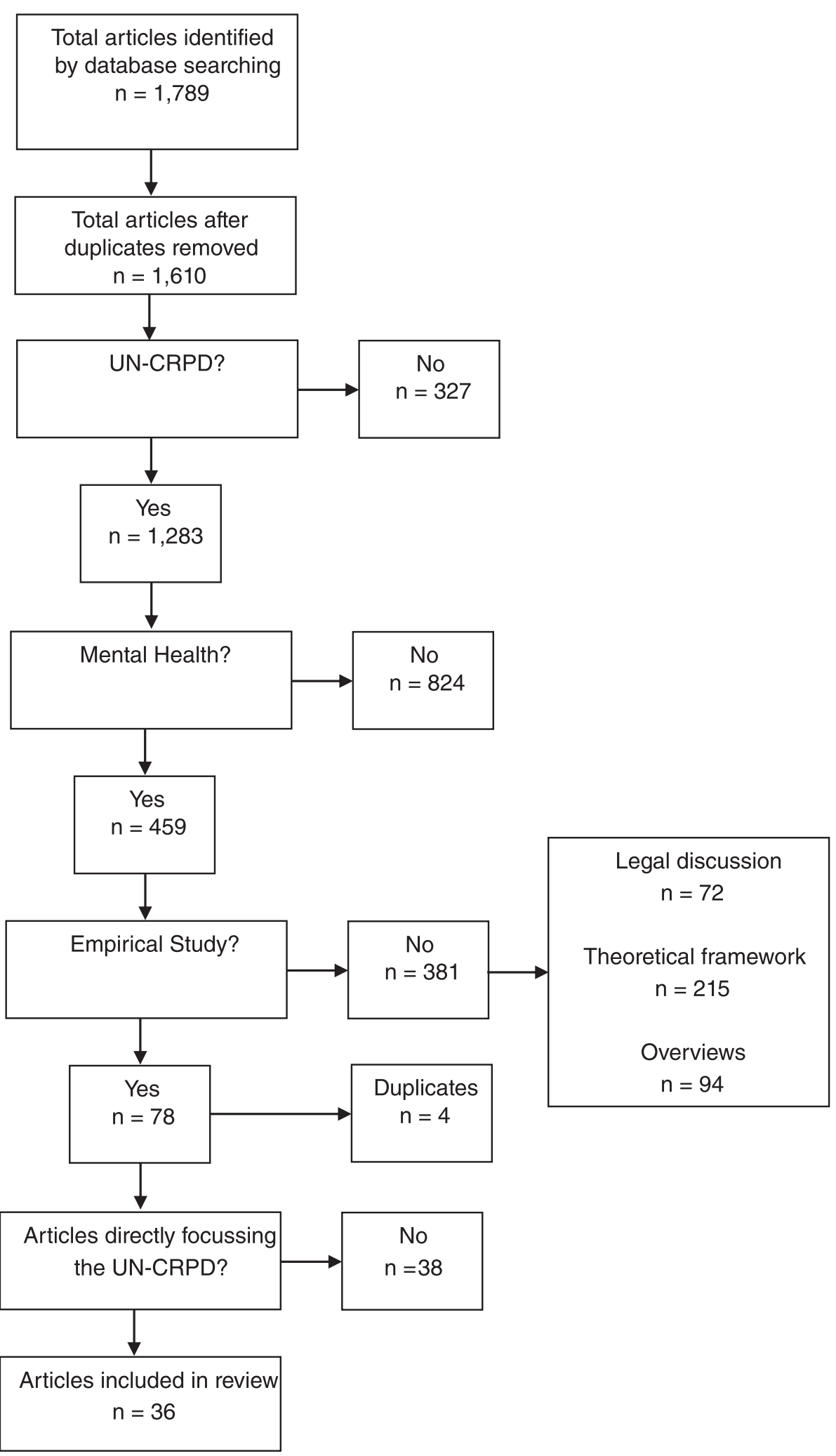

Fig. 1 Flow diagram 
Ambiguous cases were only included after discussions between the researchers. This final screening phase resulted in studies which were judged as directly inspired by the UN-CRPD. Those studies can be seen as direct product of the convention and their research was carried out in the light of the UN-CRPD.

\section{Results}

In the first-stage process, we identified 1,610 studies. 327 studies were excluded because they did not cover the UN-CRPD, 824 studies were excluded because they did not cover mental health, and 381 studies were excluded because they were non-empirical. So after the first screening process 78 studies remained. After 4 duplicates had been removed, 74 articles were assessed on basis of the full-text content. In this second-stage process, 38 studies turned out to be not directly focussing on the content of the UN-CRPD. Eventually 36 articles could be included.

Those 36 relevant studies were categorized into two groups. The first group incorporates all publications in the area of intellectual disabilities (ICD-10 F 7x) which are displayed in Table 1 . In total, there are 25 publications in the realm of intellectual disabilities representing $69 \%$ of all included studies. The second group contains all publications on other mental disorders which are displayed in Table 2 . There are 11 publications on mental disorders representing $31 \%$ of the included studies. The included studies were carried out in 22 countries illustrating the global dimension of the UN-CRPD. The country with the highest number of studies is Australia $(8,22 \%)$. The included studies employed multi-method approaches ranging from randomised controlled trials (RCTs) to different quantitative and qualitative approaches. In total, there are 2 RCTs (6 \%), 17 quantitative studies (47\%) and 17 qualitative articles (47\%).

Table 3 depicts a typology of all included studies from Tables 1 and 2. To categorise the multitude of diverse studies, we identified four major themes of research in light of the UN-CRPD. The first major theme is the realisation of the UN-CRPD and comprises all studies which investigate the gap between the aspirations of the convention and reality. While realisation consequently describes the practical fulfilment of the UN-CRPD, the second major theme termed 'implementation and financing' describes the legal fulfilment of the UN-CRPD. Studies belonging to this major theme analyse the implementation of the UN-CRPD in national legislation and as one specific aspect the financial framework as an indispensable condition for an effective implementation. The third major theme of studies inspired by the UNCRPD is the development of instruments to capture the realisation of the convention. While the aim of those instruments is eventually to quantify the realisation of the
UN-CRPD, articles belonging to this category focus rather on the construction of instruments than on the realisation as such. The last major theme we identified were attitudes towards the fulfilment of rights which are enshrined in the convention and the general awareness of the population of those rights. Studies belonging to this group analyse the realisation of the convention in people's minds as an essential precondition for a realisation in practical terms. Taken together, there are 27 studies (75\%) focusing on the realisation of the UN-CRPD, 3 studies (8 \%) investigating the implementation and financing, 3 articles $(8 \%)$ concerned with the development of instruments and 3 studies $(8 \%)$ analysing attitudes towards the UN-CRPD. Table 3 shows that 16 studies (44\%) apply a broad perspective focusing on the UN-CRPD as a whole, while 20 studies (56 \%) investigate individual articles of the convention.

\section{Discussion}

The most important result of this review was what it did not find: an appropriate amount of research in mental health care reflecting the importance of the UN-CRPD. Empirical research on aspects of the UN-CRPD is still scarce. This is in sharp contrast with the huge impact it could and probably will have on the complete organisation and structure of mental health care in all ratifying countries. 25 out of 36 studies that could be included (69\%) were related to intellectual disabilities, which was an unexpected result. Intellectual disabilities fall into the definition of mental disorders as classified in the ICD-10, chapter F (F 7) and thus fulfilled our inclusion criteria, but in most countries service provision and care is separate from other mental disorders. In published articles, the term 'mental disorder' typically refers to psychotic and affective disorders, though intellectual disabilities and dementia are also classified as mental disorders. None of the included articles referred to dementia or acquired brain injury. Anyway, the detected body of research on intellectual disabilities provides valuable insight on important research topics which should be put on the agenda for other severe mental disorders.

The majority of studies inspired by the convention analyses to what extent the aspirations of the convention are realised in a real-world context. Drew et al. [7] find a wide range of violations of the convention's aims in lowincome and middle-income countries. Kogstad [8] demonstrates that there is also a gap between human rights aims and patients' experiences in a high-income country. To bridge the gap between aspirations and reality, Vijayalakshmi et al. [9] assign the right to education a catalyst function. Successful examples of realisation of the UN-CRPD are represented by the studies by O'Brien et al. [10] and O'Connor et al. [11] who show the positive effects of inclusion in postsecondary education. In the 
Table 1 Publications on intellectual disabilities

\begin{tabular}{|c|c|c|c|c|}
\hline Relevant publications & Subject & Main results & Country & Materials and methods \\
\hline $\begin{array}{l}\text { Feldman et al. } \\
\text { (2012) [31] }\end{array}$ & $\begin{array}{l}\text { preliminary evaluation of health } \\
\text { rights training }\end{array}$ & $\begin{array}{l}\text { training group made significantly } \\
\text { more correct responses on post } \\
\text { training and follow-up tests }\end{array}$ & Canada & $\begin{array}{l}\text { RCT with } 6 \text { month follow-up } \\
(N=31)\end{array}$ \\
\hline $\begin{array}{l}\text { Brolan et al. } \\
\text { (2012) [32] }\end{array}$ & $\begin{array}{l}\text { meaning, perceptions and } \\
\text { experiences of advocacy by } \\
\text { family members and paid } \\
\text { support workers of adults with ID }\end{array}$ & $\begin{array}{l}\text { advocacy roles are vital to } \\
\text { people with ID }\end{array}$ & Australia & $\begin{array}{l}\text { RCT (113 parents, } 84 \text { support } \\
\text { workers of adults with ID) }\end{array}$ \\
\hline $\begin{array}{l}\text { Sermier Dessemontet } \\
\& \text { Bless (2013) [12] }\end{array}$ & $\begin{array}{l}\text { the impact of including children } \\
\text { with ID in general education } \\
\text { classrooms with support on the } \\
\text { academic achievement of their } \\
\text { low-, average-, and high- } \\
\text { achieving peers without } \\
\text { disabilities }\end{array}$ & $\begin{array}{l}\text { no significant difference in the } \\
\text { progress of the low-, average- } \\
\text { and high-achieving pupils from } \\
\text { classrooms with or without } \\
\text { inclusion }\end{array}$ & Switzerland & $\begin{array}{l}\text { quasi-experimental study } \\
(N=404)\end{array}$ \\
\hline Gray et al. (2014) [33] & $\begin{array}{l}\text { changes in living arrangements } \\
\text { and participation in daytime } \\
\text { activities over time in a } \\
\text { community population of young } \\
\text { people with ID }\end{array}$ & $\begin{array}{l}\text { adequate provision of } \\
\text { accommodation and } \\
\text { employment services for young } \\
\text { adults with ID is lacking }\end{array}$ & Australia & $\begin{array}{l}\text { quantitative longitudinal study } \\
(N=536)\end{array}$ \\
\hline $\begin{array}{l}\text { McConkey \& Leavey } \\
\text { (2013) [22] }\end{array}$ & $\begin{array}{l}\text { changes from } 2001 \text { to } 2011 \text { in } \\
\text { Irish attitudes towards the right } \\
\text { to sexual fulfilment of persons } \\
\text { with ID }\end{array}$ & $\begin{array}{l}\text { in } 2011 \text {, half the people in the } \\
\text { survey thought that people with } \\
\text { ID had the right to sexual } \\
\text { relationships }\end{array}$ & Ireland & $\begin{array}{l}\text { quantitative study in } 2001 \\
(N=1000) \text {, in } 2006(N=1004) \text {, } \\
\text { in } 2011(N=1039)\end{array}$ \\
\hline $\begin{array}{l}\text { Badia et al. } \\
\text { (2013) [16] }\end{array}$ & $\begin{array}{l}\text { leisure activities of persons with } \\
\text { ID }\end{array}$ & $\begin{array}{l}\text { leisure activities and recreation } \\
\text { activities were mostly solitary } \\
\text { and passive in nature; age, type } \\
\text { of schooling and severity of } \\
\text { disability determine participation }\end{array}$ & Spain & $\begin{array}{l}\text { cross-sectional quantitative study } \\
(N=237)\end{array}$ \\
\hline Gobrial (2012) [24] & $\begin{array}{l}\text { awareness of human rights of } \\
\text { children with ID in Egypt }\end{array}$ & $\begin{array}{l}\text { widespread lack of awareness of } \\
\text { the rights of children with ID; } \\
\text { respondents believed that these } \\
\text { children had limited access to } \\
\text { mental health care, social care, } \\
\text { education and rehabilitation }\end{array}$ & Egypt & $\begin{array}{l}\text { quantitative study, parents of } \\
\text { children with ID }(N=72) \text {, } \\
\text { professionals }(n=50) \text {, neither } \\
\text { parents nor professionals }(n=78)\end{array}$ \\
\hline $\begin{array}{l}\text { Stancliffe et al. } \\
\text { (2011) [18] }\end{array}$ & $\begin{array}{l}\text { benchmark on the degree of } \\
\text { choice exercised by adult service } \\
\text { users with ID in the USA }\end{array}$ & $\begin{array}{l}\text { individuals living in their own } \\
\text { home or an agency-operated } \\
\text { apartment were more likely to } \\
\text { choose where and with whom } \\
\text { they live than individuals in } \\
\text { nursing homes, institutions or } \\
\text { group homes }\end{array}$ & USA & quantitative study $(N=6778)$ \\
\hline
\end{tabular}


Table 1 Publications on intellectual disabilities (Continued)

Dusseljee et al.

(2011) [34]

Badia et al. (2011) [17]

Aznar et al. (2012) [26]

Martin \& Cobigo

(2011) [35]

Drew et al. (2011) [7]

Fasching (2012) [36]

Gomez et al. (2011) [37]

Garcia Iriarte et al.

(2014) [38] variations in community

participation in the domains

work, social contacts and leisure

activities among people with ID

influence of persona

characteristics and environmenta factors on the participation in leisure activities of people with ID

testing the usefulness of the ITINERIS scale on the rights of persons with intellectual disabilities (ISRPID)

improving the understanding of the concept of social inclusion and its indicators

types of human rights violations experienced by people with mental and psychosocial disabilities in low-income and middle-income countries

\section{access to labour market} measures to enhance vocational participation for people with ID

Exploratory investigation about implementation of human rights according to UN-CRPD

main issues for people with ID in Ireland most people with ID in the

Netherlands have work or other

Netherlands have work or other

daytime activities, have social

activities; people with ID in

general hardly participate in

activities with people without ID

participation in leisure activities is

determined more by personal

factors and perceived barriers

than by disability-related factors

the ISRPID can be an appropriate scale to monitor the UN-CRPD

rights at an individual or group

level

a clear definition of inclusion and

its measurement is needed for

decision-makers and service

providers

wide range of human rights

violations including the inability

to access adequate mental

health services or being

subjected to stigma and

discrimination

\section{vocational guidance}

predominates qualifying

measures and measures directly

aiming at integration on the

regular labour market

many situations of abuse and

negligence are still existing.

Violation of privacy recognized as

major problem by both groups

core concerns: Living options,

employment, relationships,

citizenship, leisure time, money

management, self-advocacy and

communication
Netherlands

quantitative study ( $N=653)$

Spain

cross-sectional quantitative study $(N=237)$

705 persons with ID, control group of 524 college students

Canada

retrospective analyses with adults residing in institutions ( $N=1014$ ) and with adults receiving

community-based residentia services $(n=327)$

Belize, Bosnia and

Herzegovina (and others)

survey ( $N=51$ people with

mental and psychosocial

disabilities from 18 countries)

and review of literature

Austria

nationwide survey ( $N=625$

persons with ID participating in vocational measures)

Spain

quantitative study ( $N=586$

persons with ID in defined

services and $N=161$

professionals in the same

services)

Ireland

national study involving 23 focus groups $(N=168)$ 
Table 1 Publications on intellectual disabilities (Continued)

McConkey et al.

(2013) [14]

O'Connor et al.

(2012) [11]

Saaltink et al.

(2012) [39]

Hillman et al.

(2012) [40]

Shaw et al.

(2011) [19]

Kelly et al.

(2009) [41]

O'Brien et al.

(2009) [10] inclusion within the context of

Youth Unified Sports (which

combines of players with ID and

those without ID in the same

sport teams) as perceived by

athletes, partners, coaches, family

carers and community

representatives

lecturer responses to the

inclusion of students with ID

auditing undergraduate classes

the right to participation for

young people with ID in a family

context

issues related to human rights arising within the daily lives of people in personal support

networks that included adults

with ID

views of people with ID and

their family members regarding

preferred models of housing and

support for ageing people with

views and experiences of Irish

people with ID in the area of

sexuality and relationships

experiences of students with ID gaining access into a university setting factors which facilitate socia inclusion of athletes: personal development of athletes and partners, creation of inclusive and equal bonds, promotion of positive perception of athletes, building alliances within local communities

the initiative was strongly supported by all lecturers,

providing opportunity to

consider more inclusive

instructional approaches for all

learners

young people with ID follow an age-typical yet restricted pattern

of participation in decisions

about their lives; supported

about their lives; supported

decision-making strategies are

ecommended

maintenance of rights within a supportive environment can be facilitated by deep knowledge, respect, promotion of active participation and provision of support

the main preference were

models of housing that provide the opportunity to live in close proximity to their peers and in large groups in the community

\section{people with ID are getting}

insufficient sex education

inclusion within the university

setting led the students to see

themselves more alike than

different to their peers, they felt

more accepted, more competent

and more socially networked
Serbia, Poland, Ukraine

Germany, Hungary

ualitative study, 75 interviews in five different countries

qualitative study $(N=11)$

Canada

qualitative study $(N=10)$

qualitative study, ethnographic study of 9 personal support networks

Australia

qualitative study, focus group and individual interviews, adults with ID $(N=15)$ and family members $(n=10)$

qualitative study, focus groups $(N=15)$

qualitative study, focus groups $(N=19)$ 
Table 1 Publications on intellectual disabilities (Continued)

\begin{tabular}{|c|c|c|c|c|}
\hline $\begin{array}{l}\text { Frawley \& Bigby } \\
\text { (2011) [13] }\end{array}$ & $\begin{array}{l}\text { political orientations of advisory } \\
\text { body members with ID, their } \\
\text { participatory experiences and the } \\
\text { types of support they received }\end{array}$ & $\begin{array}{l}\text { the political perspective of } \\
\text { members with ID varied; work } \\
\text { was found hard but rewarding; } \\
\text { both practical and intangible } \\
\text { obstacles to participation were } \\
\text { encountered }\end{array}$ & Australia & $\begin{array}{l}\text { qualitative study, members of } \\
\text { disability advisory bodies with ID } \\
(N=9) \text { and without ID }(n=12)\end{array}$ \\
\hline $\begin{array}{l}\text { Cobigo } \\
\text { (2014) [42] }\end{array}$ & $\begin{array}{l}\text { lived experiences of persons with } \\
\text { intellectual and developmental } \\
\text { disabilities (IDD), identifying core } \\
\text { components of the fundamental } \\
\text { right of choice }\end{array}$ & $\begin{array}{l}\text { four components identified: } \\
\text { availability of choice } \\
\text { opportunities, provision of choice } \\
\text { options, informed cognitive } \\
\text { process and act of choosing, } \\
\text { supportive environment. }\end{array}$ & Canada & scoping review \\
\hline
\end{tabular}


Table 2 Publications on mental disorders

\begin{tabular}{|c|c|c|c|c|}
\hline Relevant publications & Subject & Main results & Country & Materials and methods \\
\hline Vijayalakshmi et al. (2013) [9] & $\begin{array}{l}\text { the role of education in ascertaining } \\
\text { human rights needs of people with } \\
\text { mental illness }\end{array}$ & $\begin{array}{l}\text { education is a mechanism for the } \\
\text { pursuit of other human rights; } \\
\text { empowerment to pursue education } \\
\text { will play an important role in } \\
\text { fulfilling the obligations of the } \\
\text { UN-CRPD }\end{array}$ & India & quantitative study $(N=100)$ \\
\hline Angermeyer et al. (2014) [23] & $\begin{array}{l}\text { changes of public attitudes towards } \\
\text { restrictions on mentally ill people }\end{array}$ & $\begin{array}{l}\text { people's views on patient rights } \\
\text { have become more liberal, but the } \\
\text { public is more inclined to restrict } \\
\text { patients' freedom in case of deviant } \\
\text { behaviour }\end{array}$ & Germany & $\begin{array}{l}\text { quantitative study, two population } \\
\text { surveys }(N=2094 ; n=3642)\end{array}$ \\
\hline Burns (2010) [43] & $\begin{array}{l}\text { budget allocations over a } 5 \text {-year } \\
\text { period between psychiatric and } \\
\text { general hospitals in KwaZulu-Natal }\end{array}$ & $\begin{array}{l}\text { mean increase in budgets was } \\
\text { considerably lower in psychiatric }(3.8 \\
\%) \text { than in general hospitals (10.2 \%) }\end{array}$ & South Africa & $\begin{array}{l}\text { quantitative study based on budget } \\
\text { allocations ( } 5 \text { psychiatric and } 7 \\
\text { general hospitals) }\end{array}$ \\
\hline Steinert et al. (2015) [44] & $\begin{array}{l}\text { Patterns of individual mobility and } \\
\text { active use of motorised vehicles }\end{array}$ & $\begin{array}{l}\text { Participants drove considerably less } \\
\text { in time and distances than general } \\
\text { population. Alcohol abuse and } \\
\text { recurrent psychiatric hospitalisation } \\
\text { were associated with exclusion }\end{array}$ & Germany & $\begin{array}{l}\text { quantitative study }(N=150) \text { with } \\
\text { participants with schizophrenia or } \\
\text { schizoaffective disorder }\end{array}$ \\
\hline Kogstad (2009) [8] & $\begin{array}{l}\text { violations of dignity considered from } \\
\text { a clients' point of view }\end{array}$ & $\begin{array}{l}\text { gap between human rights' aims } \\
\text { and clients' experiences in several } \\
\text { settings; lack of safeguards against } \\
\text { infringement }\end{array}$ & Norway & $\begin{array}{l}\text { qualitative content analysis of } 335 \\
\text { client narratives }\end{array}$ \\
\hline Nomidou (2013) [25] & $\begin{array}{l}\text { human rights in in-patient care in } \\
\text { Greek mental health facilities using } \\
\text { the WHO QualityRights toolkit }\end{array}$ & $\begin{array}{l}\text { either improvement or initiation is } \\
\text { necessary for the psychiatric clinic } \\
\text { under research to fully comply with } \\
\text { the requirements of the UN-CRPD }\end{array}$ & Greece & $\begin{array}{l}\text { qualitative study, } 21 \text { in-depth } \\
\text { interviews, documentation review } \\
\text { and observation }\end{array}$ \\
\hline Nankivell et al. (2013) [15] & $\begin{array}{l}\text { orientation of nurses to human } \\
\text { rights and access of consumers with } \\
\text { severe mental illnesses to general } \\
\text { practitioner services }\end{array}$ & $\begin{array}{l}\text { the studied nurses only rarely raised } \\
\text { the topic of human rights }\end{array}$ & Australia & $\begin{array}{l}\text { qualitative study, } 6 \text { focus groups } \\
(N=38)\end{array}$ \\
\hline Battams \& Henderson (2012) [20] & $\begin{array}{l}\text { current and potential impact of the } \\
\text { UN-CRPD on Australian legislation } \\
\text { and policy }\end{array}$ & $\begin{array}{l}\text { there is a greater focus on concerns } \\
\text { about 'negative rights' rather than } \\
\text { 'positive rights'; high rates of } \\
\text { involuntary detention and a lack of } \\
\text { access to the law for people with } \\
\text { psychiatric disabilities continue to be } \\
\text { significant problems }\end{array}$ & Australia & $\begin{array}{l}\text { qualitative study, ten interviews with } \\
\text { professionals from law, psychiatry, } \\
\text { policy and service user backgrounds }\end{array}$ \\
\hline Kleintjes et al. (2010) [21] & $\begin{array}{l}\text { current support for mental health } \\
\text { care user participation in policy } \\
\text { development and implementation in } \\
\text { South Africa }\end{array}$ & $\begin{array}{l}\text { mental health care user consultation } \\
\text { in policy development and } \\
\text { implementation has been limited; } \\
\text { however, most respondents felt that } \\
\text { inclusion of user perspectives in } \\
\text { policy processes would improve } \\
\text { policy development }\end{array}$ & South Africa & $\begin{array}{l}\text { qualitative study, semi-structured } \\
\text { interviews }(N=96) \text { and policy } \\
\text { document analysis }\end{array}$ \\
\hline
\end{tabular}


Table 2 Publications on mental disorders (Continued)

\begin{tabular}{|c|c|c|c|c|}
\hline Randall et al. (2012) [27] & $\begin{array}{l}\text { producing a toolkit to document } \\
\text { violations and good practice with } \\
\text { the aim of preventing human rights } \\
\text { violations and improving general } \\
\text { health care practice in psychiatric } \\
\text { and and social care institutions }\end{array}$ & $\begin{array}{l}\text { the toolkit has demonstrated } \\
\text { applicability and is qualified as } \\
\text { acceptable and feasible for the } \\
\text { systematic monitoring of human } \\
\text { rights in psychiatric and social care } \\
\text { institutions }\end{array}$ & UK (and others) & $\begin{array}{l}\text { methodological and implementation } \\
\text { study conducted across } 15 \text { European } \\
\text { countries in monitoring visits to } 87 \\
\text { mental health organizations }\end{array}$ \\
\hline Henderson \& Battams (2011) [45] & $\begin{array}{l}\text { access and barriers to physical and } \\
\text { mental health care }\end{array}$ & $\begin{array}{l}\text { main barriers to the achievement to } \\
\text { the right of health are structural (e.g. } \\
\text { competing laws, political barriers) }\end{array}$ & Australia & $\begin{array}{l}\text { qualitative study, interviews with } 10 \\
\text { key stakeholders }\end{array}$ \\
\hline
\end{tabular}


Table 3 Typology of publications in the context of the UN-CRPD

\begin{tabular}{|c|c|c|c|}
\hline Major theme & Subthemes & Subject & $\begin{array}{l}\text { References of relevant } \\
\text { publications }\end{array}$ \\
\hline \multirow[t]{18}{*}{ Realisation } & Key concerns of people with ID & UN-CRPD as a whole & {$[37,38]$} \\
\hline & Types of human rights violations & UN-CRPD as a whole & {$[7,8]$} \\
\hline & $\begin{array}{l}\text { Living arrangements and participation } \\
\text { in daytime activities of people with ID }\end{array}$ & UN-CRPD as a whole & [33] \\
\hline & $\begin{array}{l}\text { Impact of inclusion on peers without } \\
\text { disabilities }\end{array}$ & UN-CRPD as a whole & [12] \\
\hline & $\begin{array}{l}\text { The right of participation of people } \\
\text { with ID }\end{array}$ & UN-CRPD as a whole & {$[34,39]$} \\
\hline & $\begin{array}{l}\text { Protection of rights in support } \\
\text { networks }\end{array}$ & UN-CRPD as a whole & [40] \\
\hline & $\begin{array}{l}\text { Freedom of choice of persons } \\
\text { with IDD }\end{array}$ & Article 3, 19 (Choice) & [42] \\
\hline & Choice of living arrangements & Article 3, 19 (Choice) & {$[18,19]$} \\
\hline & Social inclusion of people with ID & Article 19 (Social inclusion) & {$[14,35]$} \\
\hline & $\begin{array}{l}\text { Role of education in meeting human } \\
\text { rights needs of people with mental illness }\end{array}$ & Article 24 (Education) & [9] \\
\hline & $\begin{array}{l}\text { Inclusion of people with ID in } \\
\text { postsecondary education }\end{array}$ & Article 24 (Education) & {$[10,11]$} \\
\hline & $\begin{array}{l}\text { Access to physical health care for people } \\
\text { with serious mental illness }\end{array}$ & Article 9, 25 (Health care services) & {$[15,45]$} \\
\hline & Health advocacy & Article 25 (Health) & {$[31,32]$} \\
\hline & Inclusion in political and public life & $\begin{array}{l}\text { Article } 29 \text { (Participation in } \\
\text { political and public life) }\end{array}$ & [13] \\
\hline & $\begin{array}{l}\text { Patterns of leisure participation of people } \\
\text { with developmental disabilities }\end{array}$ & Article 30 (Leisure participation) & {$[16,17]$} \\
\hline & The right to sexual self-determination & Article 23, 25 (Sexual self-determination) & [41] \\
\hline & $\begin{array}{l}\text { Access to labour market for } \\
\text { people with ID }\end{array}$ & Article 27 (Work and employment) & [36] \\
\hline & Use of motorized vehicles & Article 20 (personal mobility) & [44] \\
\hline \multirow[t]{3}{*}{ Implementation, Financing } & $\begin{array}{l}\text { Budget allocations to psychiatric } \\
\text { hospitals }\end{array}$ & UN-CRPD as a whole & [43] \\
\hline & $\begin{array}{l}\text { Impact of UN-CRPD on national } \\
\text { legislation and policy }\end{array}$ & UN-CRPD as a whole & [20] \\
\hline & $\begin{array}{l}\text { Mental health care user participation in } \\
\text { policy development and implementation }\end{array}$ & $\begin{array}{l}\text { Article } 29 \text { (Participation in political } \\
\text { and public life) }\end{array}$ & [21] \\
\hline \multirow[t]{3}{*}{ Development of instruments } & $\begin{array}{l}\text { Application of ISRPID to measure } \\
\text { the extent to which people with } \\
\text { ID exercise their rights }\end{array}$ & UN-CRPD as a whole & [26] \\
\hline & $\begin{array}{l}\text { Development of ITHACA toolkit for } \\
\text { systematic monitoring of human } \\
\text { rights violations }\end{array}$ & UN-CRPD as a whole & [27] \\
\hline & $\begin{array}{l}\text { Application of the WHO QualityRights } \\
\text { toolkit which is based on the UN-CRPD }\end{array}$ & UN-CRPD as a whole & [25] \\
\hline \multirow[t]{3}{*}{ Attitudes } & $\begin{array}{l}\text { Public attitudes towards restrictions on } \\
\text { mentally ill people }\end{array}$ & UN-CRPD as a whole & [23] \\
\hline & $\begin{array}{l}\text { Awareness of human rights of children } \\
\text { with ID }\end{array}$ & UN-CRPD as a whole & [24] \\
\hline & $\begin{array}{l}\text { Public attitudes towards the right of } \\
\text { sexual fulfilment of people with ID }\end{array}$ & Article 23, 25 (Sexual self-determination) & [22] \\
\hline
\end{tabular}


same vein, Sermier Dessemontet and Bless [12] demonstrate that there is no negative impact of inclusion on the achievements of non-disabled peers. Furthermore, the studies of Frawley and Bigby [13] and McConkey et al. [14] represent best-practice examples for the fulfilment of the principles of the convention. Other studies focus on the realisation of individual aspects of the convention such as access to physical care [15], participation in leisure activities $[16,17]$ or the choice of living arrangements $[18,19]$. While those studies offer valuable insights, there is still a lack of systematic studies investigating the realisation of the UN-CRPD as a whole.

Moreover, there is a paucity of research about the implementation of the convention into national legislation. Battams and Henderson [20] provide such a study for the context of Australia and Kleintjes et al. [21] analyse the specific aspect of mental health care user participation in policy development and implementation. While there is a multitude of articles in the judicial realm analysing and discussing the implementation of the UNCRPD, there is a lack of empirical studies concerned with this question. Also studies investigating attitudes towards the rights in the UN-CRPD and capturing the awareness of those rights are still rare. McConkey and Leavey [22] provide such a study specifically for Irish attitudes towards the right to sexual fulfilment of persons with intellectual disability. Angermeyer et al. [23] have a broader scope investigating general changes in public attitudes towards restrictions on mentally ill people. Gobrial's [24] study analyses the public awareness of children's rights with intellectual disability in Egypt. While those studies are interesting on their own, they just offer insights on specific attitudes about particular rights. There is lack of studies capturing the general awareness of the convention and general attitudes towards its meaning in the population. Finally, there are some remarkable attempts to develop instruments to capture the realisation of the UN-CRPD. While Nomidou's [25] study is based on the World Health Organization (WHO) QualityRights toolkit, Aznar et al. [26] have developed a particular instrument called ISRPID to capture the realisation of the rights of persons with intellectual disabilities. Similarly, Randall et al. [27] have developed the Institutional Treatment, Human Rights and Care Assessment (ITHACA) toolkit which allows a systematic monitoring of the rights enshrined in the UN-CRPD. Those instruments have a huge potential to serve as a base for further studies investigating the realisation of the convention's rights.

Our review has several limitations. First of all, we may have applied too narrow inclusion criteria that limited the scope of possibly relevant studies. For instance, no example of peer research, i.e. participatory research by mental health service users, could be included. The few research papers we could find had a focus slightly different from issues in the UN-CRPD, e.g. they focused on everyday experiences and individual coping strategies $[28,29]$. Although they are covering important topics that are related to rights of people with disabilities the research was not explicitly 'a direct product of the UN-CRPD' as was required in this review paper. This is indeed a shortcoming of our inclusion criteria. Similarly, we could not include some methodological articles on the improvement of methods for the research in people with particular disabilities (e.g. specific interview techniques, participatory research) although they addressed a necessary precondition of the research we were interested in [30]. Further, the reliability of the criteria could be questioned. To rate studies as empirical studies in the area of mental health and in the context of the UN-CRPD seems quite straightforward. But whether a study focused directly on the content of the UN-CRPD is to some degree vague. It is possible that other researchers would have come to a somewhat different set of included studies.

\section{Conclusions}

There is urgent need for further research in all areas covered by the UN-CRPD relating to mental disorders. Much more evidence is needed for answering the many questions that are posed by the UN-CRPD, such as how inclusion and equality can be realised for people disabled by mental disorders and what impact a change of policies, service provision, legislation, and attitudes would have on their mental health. Up to now, the different research projects have been rather isolated and often focused on specific subject areas. While the UN-CRPD has inspired several studies, those studies are rather disconnected projects than part of a coherent body of research. More research has been done in the field of intellectual disabilities as compared to the field of severe mental disorders. This offers interesting suggestions to learn from. We therefore recommend systematic and ideally transnational research projects investigating the realisation and implementation of the UN-CRPD. In particular, in the subfield of mental disorders there is still a paucity of research about the achievements of the UN-CRPD. Further research in this area would contribute to pave the way for an effective realisation of the basic principles enshrined in the UN-CRPD.

\section{Abbreviations}

ICD-10: International Statistical Classification of Diseases and Related Health Problems, 10th revision; ID: intellectual disabilities; IDD: intellectual and developmental disabilities; ISRPID: ITINERIS scale on the rights of persons with intellectual disabilities; ITHACA: Institutional Treatment, Human Rights and Care Assessment; PRISMA: Preferred Reporting Items for Systematic Reviews and Meta-Analyses; RCT: randomised controlled trial; UK: United Kingdom; UN: United Nations; UN-CRPD: United Nations Convention on the Rights of Persons with Disabilities; USA: United States of America; WHO: World Health Organization. 


\section{Funding}

The authors declare that there was no funding.

\section{Availability of data and materials}

All data supporting our findings is contained within the manuscript.

\section{Authors' contributions}

CS carried out the database search, participated in the evaluation of the identified records and drafted the manuscript. TS conceived of the study, participated in the evaluation of the identified records and helped to draft the manuscript. SJ participated in the evaluation of the identified records and helped to draft the manuscript. EF participated in the evaluation of the identified records, helped to draft the manuscript and drafted the flow diagram. All authors read and approved the manuscript.

\section{Competing interests}

The authors declare that they have no competing interests.

\section{Consent to publish}

Not applicable.

\section{Ethics and consent to participate}

Not applicable.

\section{Author details}

'University of Mannheim, Chair for Political Science IV, Mannheim, Germany. ${ }^{2}$ Department of Psychiatry and Psychotherapy I, Centres for Psychiatry Suedwuerttemberg, Ulm University, Versorgungsforschung Weissenau, Ravensburg, Germany.

Received: 3 November 2015 Accepted: 12 May 2016 Published online: 26 May 2016

\section{References}

1. United Nations. https://www.un.org/development/desa/disabilities/. Accessed 15 May 2016.

2. Wilson A, Daar AS. A Survey of International Legal Instruments to Examine Their Effectiveness in Improving Global Health and in Realizing Health Rights. J Law Med Ethics. 2013:41:89-102.

3. Lord JE, Suozzi D, Taylor AL. Lessons from the Experience of UN Convention on the Rights of Persons with Disabilities: Addressing the Democratic Deficit in Global Health Governance. JL Med Ethics. 2010;38:564.

4. United Nations. Report of the Special Rapporteur on torture and other cruel, inhuman or degrading treatment or punishment, Juan E. Méndez. 1.2.2013. http://www.hr-dp.org/files/2013/10/28/A.HRC_.22_.53_Special_ Rapp_Report.2013 .pdf. Accessed 18 May 2016.

5. Freeman MC, Kolappa K, de Almeida JMC, Kleinman A, Makhashvili N, Phakathi S, et al. Reversing hard won victories in the name of human rights: a critique of the General Comment on Article 12 of the UN Convention on the Rights of Persons with Disabilities. Lancet Psychiatry. 2015;2:844-50.

6. Moher D, Liberati A, Tetzlaff J, Altman DG. The PRISMA Group.: Preferred Reporting Items for Systematic Reviews and Meta-Analyses: The PRISMA Statement. Ann Intern Med. 2009;151.

7. Drew N, Funk M, Tang S, Lamichhane J, Chávez E, Katontoka S, et al. Human rights violations of people with mental and psychosocial disabilities: an unresolved global crisis. Lancet. 2011;378:1664-75 doi:10.1016/S0140-6736(11)61458-X.

8. Kogstad RE. Protecting mental health clients' dignity - The importance of legal control. Int J Law Psychiatry. 2009:32:383-91.

9. Vijayalakshmi P, Reddemma K, Math SB. Perceived human rights violation in persons with mental illness: role of education. Int J Soc Psychiatry. 2013;59:351-64.

10. O'Brien P, Shevlin M, O'Keefe M, Fitzgerald S, Curtis S, Kenny M. Opening up a whole new world for students with intellectual disabilities within a third level setting. Br J Learn Disabil. 2009;37:285-92. doi:10.1111/j.1468-3156.2009.00584.x.

11. O'Connor B, Kubiak J, Espiner D, O'Brien P. Lecturer Responses to the Inclusion of Students With Intellectual Disabilities Auditing Undergraduate Classes. J Policy Pract Intellect Disabil. 2012:9:247-56. doi:10.1111/jppi.12009.

12. Sermier Dessemontet $R$, Bless $G$. The impact of including children with intellectual disability in general education classrooms on the academic achievement of their low-, average-, and high-achieving peers: Journal of
Intellectual and Developmental Disability. J Intellect Dev Disabil. 2013;38:23-30. doi:10.3109/13668250.2012.757589.

13. Frawley $P$, Bigby C. Inclusion in political and public life: The experiences of people with intellectual disability on government disability advisory bodies in Australia: Journal of Intellectual and Developmental Disability. J Intellect Dev Disabil. 2011:36:27-38. doi:10.3109/13668250.2010.549465.

14. McConkey R, Dowling S, Hassan D, Menke S. Promoting social inclusion through Unified Sports for youth with intellectual disabilities: a five-nation study. J Intellect Disabil Res. 2013;57:923-35. doi:10.1111/j.1365-2788.2012.01587.x.

15. Nankivell J, Platania-Phung C, Happell B, Scott D. Access to physical health care for people with serious mental illness: a nursing perspective and a human rights perspective-common ground? Issues Ment Health Nurs. 2013:34:442-50.

16. Badia M, Orgaz MB, Verdugo MÁ, Ullán AM. Patterns and determinants of leisure participation of youth and adults with developmental disabilities. J Intellect Disabil Res. 2013;57:319-32. doi:10.1111/j.1365-2788.2012.01539.x.

17. Badia M, Orgaz BM, Verdugo MA, Ullán AM, Martínez MM. Personal factors and perceived barriers to participation in leisure activities for young and adults with developmental disabilities. Res Dev Disabil. 2011:32:2055-63. doi:10.1016/j.ridd.2011.08.007.

18. Stancliffe RJ, Lakin KC, Larson S, Engler J, Taub S, Fortune J. Choice of living arrangements. J Intellect Disabil Res. 2011;55:746-62. doi:10.1111/j.1365-2788.2010.01336.x.

19. Shaw K, Cartwright C, Craig J. The housing and support needs of people with an intellectual disability into older age. J Intellect Disabil Res. 2011:55:895-903. doi:10.1111/j.1365-2788.2011.01449.x

20. Battams S, Henderson J. The Right to Health, International Human Rights Legislation and Mental Health Policy and Care Practices for People with Psychiatric Disability. Psychiatry Psychol Law. 2012;19:314-24.

21. Kleintjes S, Lund C, Swartz L, Flisher A, MHaPP Research Programme Consortium Mental health care user participation in mental health policy development and implementation in South Africa. Int Rev Psychiatry. 2010;22:568-77.

22. McConkey R, Leavey G. Irish attitudes to sexual relationships and people with intellectual disability. Br J Learn Disabil. 2013:41:181-8. doi:10.1111/bld.12036.

23. Angermeyer MC, Matschinger $\mathrm{H}$, Schomerus $\mathrm{G}$. Attitudes of the German public to restrictions on persons with mental illness in 1993 and 2011. Epidemiol Psychiatr Sci. 2014;23:263-70.

24. Gobrial E. Mind the gap: the human rights of children with intellectual disabilities in Egypt. J Intellect Disabil Res. 2012;56:1058-64. doi:10.1111/ j.1365-2788.2012.01650.x.

25. Nomidou A. Standards in mental health facilities-an in depth case study in Greece using the WHO QualityRights tool. J Public Ment Health. 2013;12:201-11.

26. Aznar AS, González Castañón D, Olate G. The ITINERIS scale on the rights of persons with intellectual disabilities: development, pilot studies and application at a country level in South America. J Intellect Disabil Res. 2012;56:1046-57. doi:10.1111/j.1365-2788.2012.01651.x.

27. Randall J, Thornicroft G, Burti L, Katschnig H, Lewis O, Russo J, et al. Development of the ITHACA Toolkit for monitoring human rights and general health care in psychiatric and social care institutions. Epidemiol psychiatr Sci. 2013;22:241-54

28. Corr McEvoy S, Keenan E. Attitudes towards People with Disabilities - what do people with intellectual disabilities have to say? Br J Learn Disabil. 2013;42:221-7.

29. Northway R, Bennett D, Melsome M, Flood S, Howarth J, Jones R. Keeping Safe and Providing Support: A Participatory Survey About Abuse and People With Intellectual Disabilities. J Policy Pract Intellect Disabil. 2010;10:236-44.

30. García Iriarte E, O'Brien P, Chadwick D. Involving People With Intellectual Disabilities Within Research Teams: Lessons Learned from an Irish Experience. J Policy Pract Intellect Disabil. 2014;11:149-57.

31. Feldman MA, Owen F, Andrews A, Hamelin J, Barber R, Griffiths D. Health self-advocacy training for persons with intellectual disabilities. J Intellect Disabil Res. 2012;56:1110-21. doi:10.1111/j.1365-2788.2012.01626.x

32. Brolan CE, Boyle FM, Dean JH, Taylor Gomez M, Ware RS, Lennox NG. Health advocacy: a vital step in attaining human rights for adults with intellectual disability. J Intellect Disabil Res. 2012:56:1087-97. doi:10.1111/j.1365-2788.2012.01637.x

33. Gray KM, Piccinin A, Keating CM, Taffe J, Parmenter TR, Hofer S, et al. Outcomes in young adulthood: are we achieving community participation and inclusion? J Intellect Disabil Res. 2014:58:734-45. doi:10.1111/jir.12069.

34. Dusseljee JCE, Rijken PM, Cardol M, Curfs LMG, Groenewegen PP. Participation in daytime activities among people with mild or moderate intellectual disability. J Intellect Disabil Res. 2011;55:4-18. doi:10.1111/j.1365-2788.2010.01342.x. 
35. Martin L, Cobigo V. Definitions Matter in Understanding Social Inclusion. J Policy Pract Int Disabil. 2011;8:276-82. doi:10.1111/j.1741-1130.2011.00316.x.

36. Fasching H. Partizipation von Frauen und Männern an arbeitsmarktpolitischen Maßnahmen. Heilpädagogische Forschung. 2012:38:79-88.

37. Gomez LE, Verdugo MA, Arias B, Irurtia MJ. Evaluación de los derechos de las personas con discapacidad intelectual: estudio preliminar [Assessment of rights of people with intellectual disability: preliminary study]. Behav Psychol Psicología Conductual. 2011;19:207-22.

38. García Iriarte E, O'Brien P, McConkey R, Wolfe M, O'Doherty S. Identifying the Key Concerns of Irish Persons with Intellectual Disability. J Appl Res Intellect Disabil. 2014;27:564-75. doi:10.1111/jar.12099.

39. Saaltink R, MacKinnon G, Owen F, Tardif-Williams C. Protection, participation and protection through participation: young people with intellectual disabilities and decision making in the family context. J Intellect Disabil Res. 2012:56:1076-86. doi:10.1111/j.1365-2788.2012.01649.x.

40. Hillman A, Donelly M, Whitaker L, Dew A, Stancliffe RJ, Knox M, et al. Experiencing rights within positive, person-centred support networks of people with intellectual disability in Australia. J Intellect Disabil Res. 2012;56:1065-75. doi:10.1111/j.1365-2788.2012.01647.x.

41. Kelly G, Crowley H, Hamilton C. Rights, sexuality and relationships in Ireland: 'It'd be nice to be kind of trusted'. Br J Learn Disabil. 2009;37:308-15. doi:10.1111/j.1468-3156.2009.00587.x.

42. Cobigo V. What Should Service Providers Know When Measuring How They Impact Consumers' Freedom to Make Choices? J Dev Disabil. 2014;20.

43. Burns JK. Mental health services funding and development in KwaZulu-Natal: a tale of inequity and neglect. SAMJ. 2010;100:662-6.

44. Steinert T, Veit F, Schmid P, Snellgrove BJ, Borbé R. Participating in mobility: People with schizophrenia driving motorized vehicles. Psychiatry Res. 2015;228:719-23.

45. Henderson J, Battams S. Mental health and barriers to the achievement of the'right to health'. Aust J Prim Health. 2011;17:220-6.

\section{Submit your next manuscript to BioMed Central and we will help you at every step:}

- We accept pre-submission inquiries

- Our selector tool helps you to find the most relevant journal

- We provide round the clock customer support

- Convenient online submission

- Thorough peer review

- Inclusion in PubMed and all major indexing services

- Maximum visibility for your research

Submit your manuscript at www.biomedcentral.com/submit 